\title{
Characteristics of Gypsum Recycling in Different Cycles
}

\author{
Sayonara M. M. Pinheiro and Gladis Camarini
}

\begin{abstract}
In Brazil, the gypsum plaster waste is $4 \%$ to $15 \%$ of construction and demolition waste. The environmental legislation advises that this waste should be recycled to avoid the contamination of soil and groundwater. The aim of this work is to show that the recycled gypsum plaster maintains its characteristics when submitted to different recycling cycles. The recycled gypsum plasters were produced by grinding and burning the waste along three successive recycling cycles. The recycled materials were evaluated by chemical and physical properties. The obtained results showed that both recycled and commercial gypsum plaster are similar to using in the Construction Industry.
\end{abstract}

Index Terms-Gypsum plaster, physical properties, recycling, waste.

\section{INTRODUCTION}

Gypsum plaster or "plaster of Paris" is an air-hardening binding material. It is produced from calcination of gypsum $\left(\mathrm{CaSO}_{4} \cdot 2 \mathrm{H}_{2} \mathrm{O}\right.$ - calcium sulfate dihydrate), that partially dehydrates producing gypsum plaster $\left(\mathrm{CaSO}_{4} \cdot 0.5 \mathrm{H}_{2} \mathrm{O}-\right.$ calcium sulfate hemihydrate) [1], [2].

In Brazil, the gypsum plaster used as construction material is obtained by drying calcination of natural gypsum rock at temperatures ranging from $140{ }^{\circ} \mathrm{C}$ to $200{ }^{\circ} \mathrm{C}$ as in (1). It is called $\beta$-hemihydrate, which is constituted of calcium sulfate hemihydrate $\left(\mathrm{CaSO}_{4} \cdot 0.5 \mathrm{H}_{2} \mathrm{O}\right)$, anhydrite III - unstable $\left(\mathrm{CaSO}_{4} \cdot \mathrm{EH}_{2} \mathrm{O}-0.06<\varepsilon<0.11\right)$, anhydrite II - insoluble $\left(\mathrm{CaSO}_{4}\right)$, calcium sulfate dihydrate $\left(\mathrm{CaSO}_{4} \cdot 2 \mathrm{H}_{2} \mathrm{O}\right)$ and smaller amounts of impurities [3]-[4].

$$
\mathrm{CaSO}_{4} \cdot 2 \mathrm{H}_{2} \mathrm{O} \stackrel{140 \text { to } 200^{\circ} \mathrm{C}}{\longrightarrow} \mathrm{CaSO}_{4} \cdot 0.5 \mathrm{H}_{2} \mathrm{O}+1.5 \mathrm{H}_{2} \mathrm{O}
$$

The presence of these calcium sulfate phases is the result of different interaction such as temperature; water pressure of calcination environment inside the kiln; particle size distribution and residence time [5].

The presence and amount of each calcium sulfate phase

Manuscript received April 5, 2014; revised July 1, 2014. This work was supported in part by the Civil Engineering Graduate Program of the School of Civil Engineering, Architecture and Urban Design, University of Campinas, Brazil. The authors thank the National Counsel of Technological and Scientific Development - CNPq and the Brazilian Federal Agency for Support and Evaluation of Postgraduate Education - CAPES for the scholarships.

Sayonara M. M. Pinheiro is with the Department of Civil Engineering at Federal University of Espírito Santo, UFES, Brazil (e-mail: sayonara.pinheiro@gmail.com).

Gladis Camarini is with the Civil Engineering and Urban Design at University of Campinas, UNICAMP. Campinas, São Paulo, Brazil, Av. Albert Einstein, 951, POBox 6021, CEP: 13083-852, Campinas, SP, Brazil (e-mail: gcamarini@gmail.com, camarini@fec.unicamp.br). provide to the final product (commercial gypsum plaster) different behavior, changing the kinetic of hydration reactions and, consequently, their mechanical properties [5].

Commercial gypsum plaster from Brazil is constituted manly by hemihydrates whose contents ranges from $54.8 \%$ to $96.2 \%$; anhydrite contents ranges from $0.0 \%$ to $19.0 \%$ and dihydrates contents ranges from $0.0 \%$ to $10.0 \%$ [3].

Gypsum plaster is used in building constructions such as pastes, mortars, components (plasterboards, masonry blocks and ceilings) and decorative elements [3].

To be used, it is mixed with water. In contact with water, gypsum hemihydrates particles reacts, rehydrating and become a hard mass, by an exothermic reaction, showed in (2) $[6]$.

$$
\mathrm{CaSO}_{4} \cdot 0.5 \mathrm{H}_{2} \mathrm{O}+1.5 \mathrm{H}_{2} \mathrm{O} \longrightarrow \mathrm{CaSO}_{4} \cdot 2 \mathrm{H}_{2} \mathrm{O}
$$

The mechanism of hydration reaction is explained by Le Chatellier. When mixing the materials, hemihydrates $\left(\mathrm{CaSO}_{4} \cdot 0.5 \mathrm{H}_{2} \mathrm{O}\right)$ are dissolved in water, forming a saturated solution of $\mathrm{Ca}^{2+}$ and $\mathrm{SO}_{4}{ }^{2-}$ ions, followed by precipitation of acicular dihydrate crystals $\left(\mathrm{CaSO}_{4} \cdot 2 \mathrm{H}_{2} \mathrm{O}\right)$. So, the crystallization nuclei are formed and around it the crystals grow, forming an interlocking net of long crystals providing the strength of the material [1]-[7]. The resulting material is calcium sulfate dihydrate $\left(\mathrm{CaSO}_{4} \cdot 2 \mathrm{H}_{2} \mathrm{O}\right)$ having the same chemical nature of the natural gypsum rock [8].

During the hydration process the microstructure of the hardened paste is defined. It depends on the water/gypsum rate, responsible to lead the hydration reactions and to keep the workability of gypsum slurry. In general, when the water amount increase the voids fractions increase and the bond between the gypsum crystals decrease, leading to lower the strength of the material [9], [10].

According to Kojima and Yasue [11], the water required to keep the workability of gypsum slurry is a function of the particle size distribution, as well as, it varies to the particle diameter (fineness) and the uniformity coefficient (size).

In general, the amount of water increases with the decreasing of the particle diameter and with the increasing of the coefficient of uniformity. However, small changes in the particle size distribution can reduce the workability of the pastes, even when the materials have the same specific surface area [11].

In Brazil, during the construction process a significant amount of gypsum plaster waste is generated, being in the range of $4 \%$ to $15 \%$ of construction and demolition waste [12]. The forming waste depends on the constructive process used, as well as, the culture of the region. In 2012, the amount of gypsum plaster waste in Brazil was about 5.400.000 t. However, this number could be greatly increased due to the lack of data control related to gypsum plaster waste [13].

This waste material is mainly composed of calcium sulfate 
dihydrate $\left(\mathrm{CaSO}_{4} \cdot 2 \mathrm{H}_{2} \mathrm{O}\right)$ which is not inert and contaminates soil and groundwater. Brazilian Environmental Legislation establishes that the gypsum waste should be recycled or placed on specific areas. However, the gypsum plaster waste is found in irregular areas due to the absence of specific landfills and mostly by the lack of inspection by the government, as well as by few recycling plants [12].

Recent researches of gypsum plaster waste recycling are related to the use as dihydrate, mixing it with hemihydrates to use as renderings, or as raw material in the production of Portland cement and plasterboards [11]-[14].

Due to the chemical characteristics of gypsum plaster waste, this material can be recycled as a binding material by a simple recycling process, similar to the industrial process to produce commercial plaster [15]. Recent studies showed similar characteristics between recycled gypsum plaster (RGP) and commercial gypsum plaster (CGP) assessed by thermal analyses (TG/DTG) [16] and crystal morphology (SEM) [8]. However, there is little information about the properties of this recycled material when it is recycled several times.

This study evaluates the chemical and physical properties of RGP along three successive recycling cycle processes to evaluate the characteristics and properties of the recycled material.

\section{MATERIALS AND MethodS}

\section{A. Materials}

The materials used in this experimental work were commercial gypsum plaster (CGP) obtained in the Brazilian market; and recycled gypsum plaster, obtained by grinding and burning the gypsum plaster waste (GPW) three times. The properties were evaluated in the first cycle (RGP-1) and the third one (RGP-3).

\section{B. Recycling Process}

The recycling process was made by grinding and burning the waste (GPW). The GPW was crushed in a ball mill reaching a fineness modulus of less than 1.10 , homogenized and burned in a stationary oven at $150{ }^{\circ} \mathrm{C}$ for 1 hour.

\section{Recycling Cycles}

Recycled gypsum plaster from the first (RGP-1) and the third (RGP-3) cycles were obtained by successive recycling of the GPW (Fig. 1).

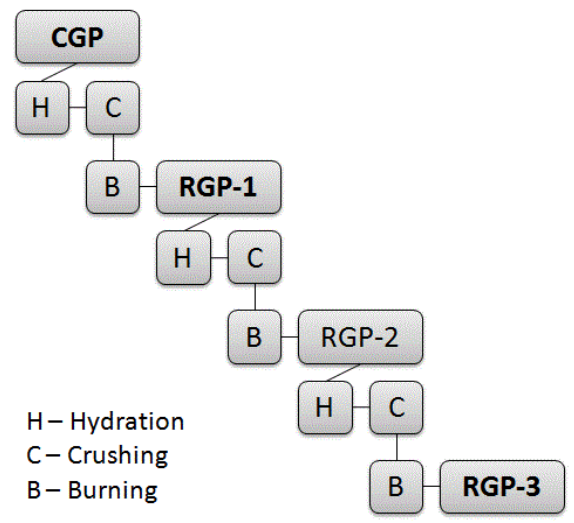

Fig. 1. Recycling cycles to obtain RGP-1 and RGP-3.

\section{Homogenization}

The recycled gypsum plaster (RGP-1 and RGP-2) was homogenized by the method proposed by Cheverton [17]. The material is distributed along successive layers that are piled in alternate directions, with continuous and uniform distribution (Fig. 2).

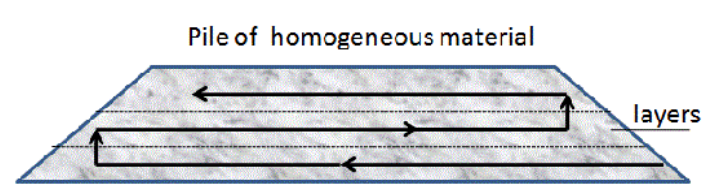

Fig. 2. Homogenization of the recycling gypsum plaster (RGP-1 and RGP-3).

\section{E. Evaluated Properties}

CGP, RGP-1 and RGP-3 were evaluated by physical proprieties and chemical characteristics such as particle size distribution, bulk unit weight; specific gravity; specific surface area; free water, water crystallization, calcium oxide, sulfuric anhydride; thermal analysis by TGA/DTGA and X-ray diffraction (XRD).

TGA/DTGA was made in a Shimadzu detector (TGA-50), with Nitrogen atmosphere at heating at a rate of $10{ }^{\circ} \mathrm{C} / \mathrm{min}$ and XRD in a Shimadzu-XRD 7000.

Physical proprieties took place at the Laboratory of Binders and Wastes (LARES) at the School of Civil Engineering, Architecture and Urban Design - FEC UNICAMP. Determination of the free water, water crystallization, calcium oxide, sulfuric anhydride, TG/DTA and XRD were made at Chemistry Institute - UNICAMP.

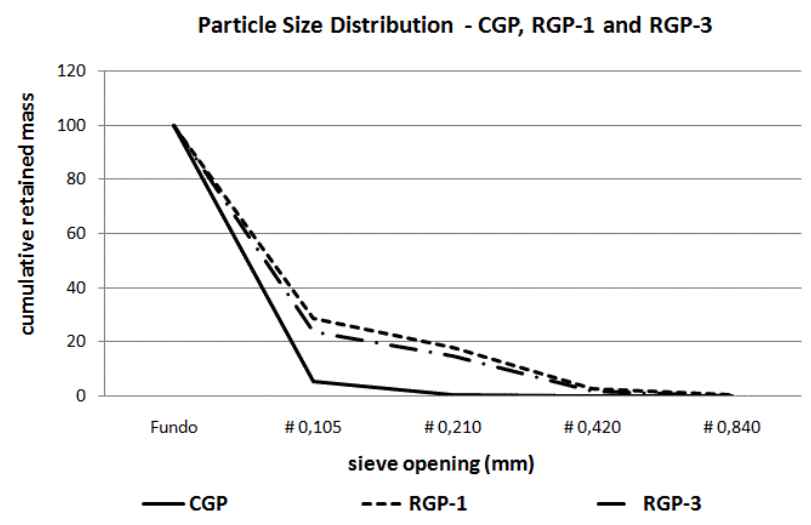

Fig. 3. Particle size distribution of commercial (CGP) and recycled (RGP-1 and RGP-3) gypsum plaster.

\section{RESULTS AND DISCUSSION}

\section{A. Physical Properties}

Table I show the results of the physical properties of commercial gypsum plaster (CGP) and recycled gypsum plaster at the first cycle (RGP-1) and third cycle (RGP-3). The particle size distribution is shown in Fig. 3.

Data were treated statistically and the results were analyzed as follows.

1) The RGP-1 and RGP-3 had the same specific gravity and specific surface area of the CGP;

2) Fineness modulus and bulk unit weight were different for RGP-1, RGP-3 and CGP; 
3) The fineness modulus increases in the following order: RGP-3 > RGP-1 > CGP;

4) The bulk unit weight decreases in the following order: RGP-3 < RGP-1 < CGP.

The difference between recycled gypsum plaster (RGP-1 and RGP-3) and commercial gypsum plaster (CGP) can be explained by the grinding step used in the recycling process. The grinding recycled process is different than the commercial one. So, they generated materials with different particle size distribution and fineness modulus. However, both of them showed fineness modulus $<1.10$, according specification of Brazilian Standards [18].

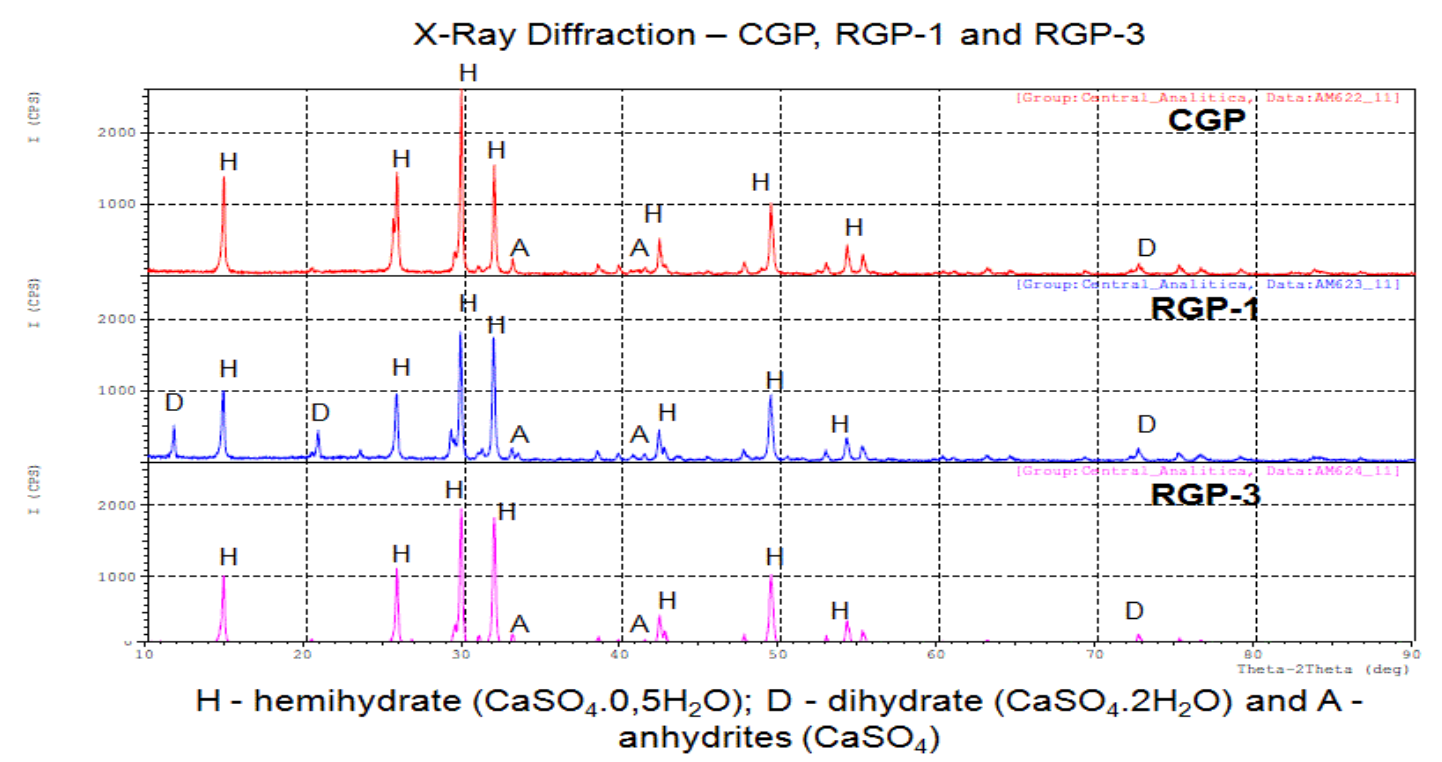

Fig. 4. X-ray Diffraction of commercial (CGP) and recycled (RGP-1 and RGP-3) gypsum plaster.

The difference between the recycled gypsum plasters are the bulk unit weight and the fineness modulus. The bulk unit weight decreases and the fineness modulus increases along the recycled cycles.

According to Pinheiro [15], during the recycling cycle some alteration can occur on the microstructure of the recycled material. The crystals become weaker, and during the grinding process, these observed physical alterations can occur.

These alterations are not desirable. The amount of water required to keep the workability of gypsum slurry, can increase, leading to the decrease of the strength of the recycled material [9], [10].

\section{B. Chemical}

The Chemical results of the commercial gypsum plaster (CGP) and recycled gypsum plaster (RGP-1and RGP-3) are presented in Tables II, III and in Fig. 4.

Table II shows the percentages of free water, water crystallization, calcium oxide $(\mathrm{CaO})$ and sulfuric anhydride $\left(\mathrm{SO}_{3}\right)$ by mass.

TABLE I: RESUlTS OF PHYSICAL PROPERTIES OF COMMERCIAL (CGP) AND RECYCLED GYPSUM PLASTER (RGP-1 AND RGP-3)

\begin{tabular}{lcccc}
\hline \hline Material & $\begin{array}{c}\text { Fineness } \\
\text { modulus }\end{array}$ & $\begin{array}{c}\text { Bulk unit } \\
\text { weight } \\
\left(\mathrm{kg} / \mathrm{m}^{3}\right)\end{array}$ & $\begin{array}{c}\text { Specific } \\
\text { gravity } \\
\left(\mathrm{kg} / \mathrm{m}^{3}\right)\end{array}$ & $\begin{array}{c}\text { Specific } \\
\text { surface area } \\
\left(\mathrm{m}^{2} / \mathrm{kg}\right)\end{array}$ \\
\hline CGP & 0.06 & 746 & 2600 & 6235 \\
\hline RGP-1 & 0.38 & 429 & 2550 & 6345 \\
\hline RGP-3 & 0.41 & 384 & 2550 & 6266 \\
\hline \hline
\end{tabular}

The values of free water, water crystallization, calcium oxide and sulfuric anhydride are auxiliary data to determine gypsum chemical composition. They are in accordance to the Brazilian Standards [18], as well as the results of Cincotto, Agopyan and Florindo [3].
TABLE II: CHEMICAL CHARACTERISTICS OF COMMERCIAL (CGP) AND RECYCLED (RGP-1 AND RGP-3) GYPSUM PLASTER

\begin{tabular}{lcccc}
\hline \hline \multirow{2}{*}{ Material } & \multicolumn{4}{c}{ Mass (\%) } \\
\cline { 2 - 5 } & $\begin{array}{c}\text { Free } \\
\text { water }\end{array}$ & $\begin{array}{c}\text { Water } \\
\text { crystallization }\end{array}$ & $\mathrm{CaO}$ & $\mathrm{SO}_{3}$ \\
\hline CGP & 1.27 & 1.04 & 37.3 & 49.9 \\
\hline RGP-1 & 0.85 & 2.96 & 39.0 & 49.4 \\
\hline RGP-3 & 1.03 & 1.91 & 39.0 & 47.0 \\
\hline \hline
\end{tabular}

TABLE III: CHEMICAL CHARACTERISTICS OF COMMERCIAL (CGP) AND RZCYCLED GYPSUM PLASTER (RGP-1 AND RGP-3)

\begin{tabular}{lcc}
\hline \hline \multirow{2}{*}{ Material } & \multicolumn{2}{c}{ Levels (\%) } \\
\cline { 2 - 3 } & $\begin{array}{l}\text { Hemihydrate } \\
\left(\mathrm{CaSO}_{4} \cdot 0.5 \mathrm{H}_{2} \mathrm{O}\right)\end{array}$ & $\begin{array}{c}\text { Dihydrate } \\
\left(\mathrm{CaSO}_{4} \cdot 2 \mathrm{H}_{2} \mathrm{O}\right)\end{array}$ \\
\hline CGP & 94.45 & - \\
\hline RGP-1 & 89.49 & 10.51 \\
\hline RGP-3 & 98.24 & - \\
\hline \hline
\end{tabular}

The XRD patterns (Fig. 3) show the calcium sulfate hemihydrate crystal $\left(\mathrm{H}-\mathrm{CaSO}_{4} \cdot 0.5 \mathrm{H}_{2} \mathrm{O}\right)$ and a small presence of calcium sulfate dihydrate $\left(\mathrm{D}-\mathrm{CaSO}_{4} \cdot 2 \mathrm{H}_{2} \mathrm{O}\right)$ and anhydrite $\left(\mathrm{A}-\mathrm{CaSO}_{4}\right)$. The hemihydrate crystal is predominant in these results.

The contents of hemihydrate $\left(\mathrm{CaSO}_{4} \cdot 0.5 \mathrm{H}_{2} \mathrm{O}\right)$ and dihydrate $\left(\mathrm{CaSO}_{4} \cdot 2 \mathrm{H}_{2} \mathrm{O}\right)$ were estimated based on TG/DTG curves that are shown in Table III.

Data were analyzed as follows:

1) CGP, RGP-1 and RGP-2 had the same chemical characteristics. All of them had a high content of hemihydrates. These results are also in accordance with Cincotto, Agopyan and Florindo [3], and

2) RGP-1 presented a significant amount of dihydrate. Although the results are in agreement with Cincotto, Agopyan and Florindo [3], it differs from RGP-3 and 
CGP due the presence of dihydrate.

The presence of dihydrate in the composition of recycled gypsum plaster at the first cycle (RGP-1) can be explained by the burned step used in the recycling process.

During calcination, the gypsum plaster compounds are formed depending on the temperature, time of calcination, particle size distribution and water vapor pressure [5].

As observed in Fig. 2 the particle size from RGP-1 and RGP-3 are different and this fact, as well as an eventual presence of water vapor pressure surrounding the particle, could lead to the presence of dihydrate in the composition of RGP-1.

\section{CONCLUSION}

This study observed the physical properties and chemical characteristics of two types of recycled gypsum plaster, obtained at first (RGP-1) and third (RGP-3) successive recycling cycles.

The recycled gypsum plasters presented chemical characteristics similar to the commercial gypsum plaster, even with different fineness, particle size distribution and bulk unit weight.

RGP-1 and RGP-3 showed a high level of calcium sulfate hemihydrate $\left(\mathrm{CaSO}_{4} \cdot 0.5 \mathrm{H}_{2} \mathrm{O}\right)$. This characteristic gives the binding properties of the recycled material, maintaining the main characteristic to be considered similar to the commercial gypsum plaster.

In this way, this study show that the gypsum plaster waste can be recycled and re-recycled several times for the same purpose than the original binder.

However, more studies must be developed to improve the recycling process. Crushing and burning steps should be controlled to maintain the recycled material quality.

\section{ACKNOWLEDGMENT}

The authors are grateful to the Brazilian Federal Agency for Support and Evaluation of Postgraduate Education CAPES, and the National Counsel of Technological and Scientific Development - CNPq for the scholarships, and LARES-FEC-UNICAMP where the tests took place.

\section{REFERENCES}

[1] J. Karni and E. Karni, "Gypsum in construction: origin and properties", Materials and Structures, vol. 28, pp. 92-100, 1995.

[2] M. Singh, "Making of gypsum plaster in Bhutan - an experience", Journal of Scientific and Industrial Research, vol. 65, pp. 826-829, October 2006.

[3] M. A. Cincotto, V. Agopyan, and M. C. Florindo, "Gypsum plaster as a construction material: chemical compound," in Technology of Building, Ed. Technological Research Institute, pp. 53-56, 1998.

[4] J. A. D. Milito and G. Camarini, "Gypsum hemihydrate-cement blends to improve renderings durability," Constr. Build. Mat. vol. 25, pp. 4121-4125, 2011.

[5] J. Moisset, Review of the Main Process Used for Plaster Products. Gypsum Fair 97, ed. Technological Institute of Pernambuco - ITEP, Brazil. 1997
[6] W. C. Hansen, "Hydration of calcined gypsum," Industrial and Engineering Chemistry, vol. 22, pp. 611-613, 1930.

[7] A. J. Lewry and J. Williamson, "The setting of gypsum plaster: part I the hydration of calcium sulphate hemihydrate," Journal of Materials Science, vol. 29, pp. 5524-5528, 1994.

[8] G. Camarini, S. M. M. Pinheiro, "Microstructure of recycled gypsum plaster by SEM," Advanced Materials Research, vol. 912-914, pp. 243-246, 2014.

[9] J. Lewry and J. Williamson, "The setting of gypsum plaster: part II The development of microstructure and strength," Journal of Materials Science, vol. 29, pp.5 524-5528, 1994.

[10] Q. L. Yu and H. J. H. Brouwers, "Microstructure and mechanical properties of b-hemihydrate produced gypsum: An insight from its hydration process," Construction and Building Materials, vol. 25, pp. 3149-3157, 2011.

[11] Y. Kojima and T. Yasue, "Synthesis of large plate-like gypsum dehydrate from waste gypsum board," Journal of the European Ceramic Society, vol. 26, pp. 777-783, 2006.

[12] G. Camarini, L. L. Pimentel, N. H. R. Sa, "Assessment of the material loss in wall renderings with B-hemihydrate paste," Applied mechanics and Materials, vol. 71-78, pp. 1242-1245, 2011

[13] ABRELPE: Brazilian Association of Public Cleaning and Special Waste. [Online]. Available: http://www. a3p.jbrj.gov.br/pdf/ABRELPE\%20\%20Panorama2012.pdf.

[14] C. Chandara, K. A. Azizli, Z. A. Ahmad, and E. Sakai, "Use of waste gypsum to replace natural gypsum as set retarders in Portland cement," Waste Management, vol. 29, pp. 1675-1679, 1999.

[15] S. M. M. Pinheiro, "Recycled gypsum plaster: properties evaluation for using in components," M.S. thesis, Graduate Program in Civil Engineering, Architecture and Urban Design - FEC, University of Campinas - UNICAMP, Campinas, Brazil, 2011.

[16] G. Camarini, S. M. M. Pinheiro, and K. Tannous, "Thermal analysis of recycled gypsum from construction and demolition waste," Applied Mechanics and Materials, vol. 260-261, pp. 977-980, 2012.

[17] I. F. Petersen, "Blending in circular and longitudinal mixing piles", Chemometrics and Intelligent Laboratory Systems, vol. 74, pp. 135-141, 2004

[18] Gypsum for Construction, ABNT Standard NBR 13207 - 1994.

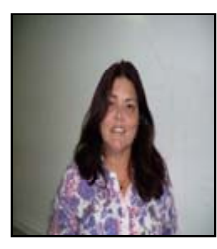

Sayonara M. M. Pinheiro was born in Brazil, 1961. She was graduated in civil engineering from the Federal University of Espírito Santo - UFES in 1986, She received her M.Sc. in civil engineering from the Federal University of Espírito Santo - UFES in 2003 and She received her PHD in civil engineering from the University of Campinas - UNICAMP in 2011.

She is currently an adjunct professor of civil engineering in Federal University of Espírito Santo - UFES - Brazil. She is teaching courses of buildings such as materials, technology, budget and planning. She conducts researches in the field of building materials such as recycling of construction waste (emphasis on gypsum plaster), concrete biodeterioration and durability/performance - concrete, mortar and plaster.

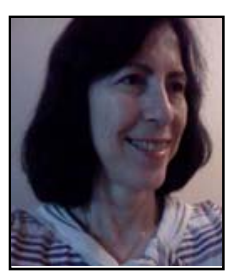

Gladis Camarini is a civil engineer and a professor at School of Civil Engineering, Architecture and Urban Design, University of Campinas. She had her master degree in 1988 and $\mathrm{PhD}$. degree in 1995 at University of São Paulo. She did postdoctoral studies at the Laboratoire des Materiaux et Durabilité des Constructions (LMDC) at Institut National des Sciences Apliquées (INSA, Toulouse, France, 1998). She also did postdoctoral studies at the National Institute for Space Research (INPE, São José dos Campos, Brazil, 2008). Then she also did postdoctoral studies at the Institute of Science and Technology del Hormigón (ICITECH), the Polytechnic School of Valencia (UPV) (Valencia, Spain, 2012). She is a peer-reviewed of scientific journals indexed on the Journal Citation Reports, national and international journals, Congress and Seminars, and Brazilian Research Foundations. She is an IACSIT senior member. Her research interests include: building materials, mineral binders, mortars, industrial and construction wastes, reusing and recycling of materials, mortar, concrete, and steam curing. 